\title{
OPTIMALISASI PETERNAKAN BABI BIBIT UNGGUL (PERSILANGAN LANDRACE DAN DUROC) BAGI PETERNAK LOKAL DI NUSA TENGGARA TIMUR
}

\author{
Redempta Wea*, Andy Yumima Ninu, Sondang Perlindungan P. Leoanak \\ Program Studi Produksi Ternak, Jurusan Peternakan, Politeknik Pertanian Negeri Kupang, Kupang, Indonesia \\ *Penulis Korespodensi : wearedempta@yahoo.co.id
}

\begin{abstract}
Abstrak
Pemeliharaan ternak babi membudaya bagi masyarakat Nusa Tenggara Timur (NTT) khususnya kelompok tani Sehati Kelurahan Tuatuka, Kecamatan Kupang Tengah, Kabupaten Kupang dengan aktivitas utama adalah budidaya tanaman pangan - holtikultura, serta usaha sampingan ternak babi. Na mun, karena keterbatasan pengetahuan pemeliharaan ternak, bibit babi bukan bibit unggul, serta pola pemeliharaan yang dila kukan secara in dividu sehingga kualitas ternak rendah dan kurang berkembang. Oleh karena itu optimalisasi dilakukan dengan cara pemeliharaan ternak babi sistim penggemukan menggunakan metode kemitraan. Tujuan kegia tan a dalah meningkatkan pengetahuan dan ketrampilan masyarakat serta meningkatkan pertumbuhan ternak babi sistim penggemukan den gan pola kemitraan. Metode kegiatan adalah pendekatan partisipatif meliputi penyuluhan, pelatihan, demplot, dan pendampingan. Hasil kegiatan adalah terjadinya peningkatan pengetahuan dan ketrampilan masyarakat, peningkatan pertumbuhan ternak babi (pertambahan bobot badan $0,18 \mathrm{~kg} /$ hari menjadi $0,36 \mathrm{~kg} / \mathrm{hari}$ dengan lama pemeliharaan lebih singkat yakni 12 bulan menjadi 5 bulan), serta hubungan sosial masyarakat yang semakin a krab. Kesimpulannya optimalisa sipemeliharaan ternak babi penggemukan dengan sistim kemitraan dapat meningkatkan pengetahuan dan ketra mpilan mitra, menghasikan performans ternak babi dengan PBB $0,36 \mathrm{~kg} /$ hari dengan la ma pemeliharaan mencapai bobot jual (60 $\mathrm{kg}$ ) selama 5 bulan, serta hubungan sosial mitra lebih akrab. Disarankan pemeliharaan babi penggemukan sistim kemitraan dapat diadopsi oleh pemerintah setempat dan dilakukan pada petemak lainnya.
\end{abstract}

Kata kunci: Babiunggul; Promitra; Pakan.

\begin{abstract}
The maintenance of pigs is entrenched for the people of East Nusa Tenggara (NTT) especially the Sehati farmer group Tuatuka Village, Kupang Tengah District, Kupang Regency with the main activities being food crop cultivation - horticulture, as well as pig livestock side businesses. However, due to limited knowledge of livestock rising, pig breedsare not superior breeds, as well as individualized maintenance patterns so that the quality of livestock is low and less developed. Therefore optimization is done by raising fattening pigs using the partnership method. The aim of the activity is to increase the community'sknowledge and skills and increase the growth offattening pigs with a partnership pattern. The method of activity is a participatory approach including counseling, training, demonstration plots, and mentoring. The results of the activity were an increase in community knowledge and skills, an increase in the growth of pigs (body weight gain of $0.18 \mathrm{~kg} /$ day to $0.36 \mathrm{~kg} /$ day with shorter maintenance times i.e. 12 months to 5 months), as well as increasingly social relations familiar. In conclusion, optimizing the maintenance of fattening pigs with a partnership system can improve partners' knowledge and skills, produce performance of pigs with PBB $0.36 \mathrm{~kg} /$ day with maintenance time reaching a selling weight (60 kg) for 5 months, as well as closer social relations of partners. It is recommended that maintenance of fattening pigs for the partnership system be adopted by the local governmentand carried out by other breeders.
\end{abstract}

Keywords: Superior Pork; Promitra; Feed.

\section{PENDAHULUAN}

Pemeliharaan ternak babi sudah membudaya di masyarakat non muslim khususnya di daerah Nusa Tenggara Timur (NTT). Populasi babi memiliki konsentrasi terbesar di Provinsi NTT, dipelihara 85\% seca ra tradisional, dan dominan dilakukan masyarakat non islam (Johns et al., 2010; Soewandi dan Talib, 2015 ) serta terjadi pergeseran pemeliharaan temak babi 
dari babi lokal ke babi persilangan (umumnya persilangan Landrace dan Duroc).

Pardosi (2004) dan Sution (2010) menyatakan bahwa pemeliharaan ternak babi dilakukan karena memiliki keunggulan yakni mampu beranak 2 kali setahun, jumlah anak yang banyak (6-12 ekor) per sekali kelahiran, mudah dipelihara dan beradaptasi, efisien da lam mengubah sisa makanan limbah rumah tangga, serta menghasilkan keuntungan relatif cepat diba ndingkan modal y ang dikeluarkan.

Namun, minimnya pengetahuan masyarakat tentang cara pemeliharaan ternak yang baik cendenung menghasilkan performans pertumbuhan temak yang kurang optimal. Selain itu, cara pemeliharaan temak ba bi yang dilakukan masyarakat pada umumnya secara individu dengan mengandalkan modal sendiri sehingga cenderung tidak berkembang jika bersaing dengan mitra yang berasal da ri swa sta.

Oleh karena itu, salah satu solusi mengoptimalkan potensi pemeliharaan ternak babi unggul tersebutadalah melaksanakan demplot pemeliharaan temak babi penggemukan melalui sistem pembinaan secara kemitraan pada kelompok peternak tertentu.

Tuatuka merupakan salah satu dari 5 kelurahan dan 7 desa di Kecamatan Kupang Timur, Kabupaten Kupang, Provinsi NTT yang mengoptimalkan potensi temakbabi sebagai komoditas ekonomi stra tegis. Budidaya temak babi tetap dipertahankan turun temurun hingga sampai saat ini karena turut memberikan kontribusi sebagai sumber pendapatan alternatif bagi petani selain usaha ta naman pangan (padi dan jagung).

Kelompok tani Sehati merupakan salah satu diantara kelompok tani yang berada di RT 02 / RW 03, Kelurahan Tuatuka, Kecamatan Kupang Timur, Kabupaten Kupang, Provinsi NTT. Kelompok tani Sehati didirikan pada tahun 2010 dan saat ini mempunyai jumlah anggota kelompok sebanyak 15 orang dengan keseharian aktivitasnya melakukan budidaya ternak babi lokal, ras dan tanaman pangan holtikultura. Jarak kelompok tani Sehati dari kampus Politeknik Pertanian Negeri Kupang $\pm 20 \mathrm{Km}$. Khusus usaha pemeliharaan ternak babi, telah dijalankan oleh 16 orang anggota kelompok tani Sehati karena dipandang cukup berperan menopang pendapatan ekonomi rumah tangga.

Kelompok tani Sehati merupakan mitra pengabdian masyarakat yang bekerja sama dengan Jurusan Peternakan Politani Negeri Kupang dalam kegiatanIbM sejak tahun 2016. Rintisan kegia tan pa da tahun 2016 dimulaidengan introduksi teknologi pengolahan limbah peternakan, dan dilanjutkan pada ta hun 2017 melalui introduksi teknologi perkandangan dan pembibitan ternak babi. Berda sarkan hasil pendampingan selama tahun 2017-2018 diketahui bahwa introduksi berbagai teknologi yang diberikan kepada anggota kelompok tani
Sehati telah berhasil memotivasi a nggota kelompok tani Sehatiuntuk terus melakukan budidaya ternak babi.

Namun, berdasarkan hasil survey lanjutan dan evaluasi diketahui bahwa usaha budidaya ternak babi yang dilakukan anggota kelompok tani Sehati memiliki berbagai hambatan. Hal tersebut berkaitan dengan terba tasnya jumlah ternak babi yang dimiliki anggota mitra, penggunaan bibit ternak babi yang didominasi ras lokal(babi ka mpung), terbatasnya modal a nggota mitra untuk meningkatkan skala usaha budidaya temak babi, kalender pemasaran ternak babi yang tidak menentu dan umumnya ditentukan oleh kebutuhan mendesak anggota mitra, kurangnya pengetahuan anggota mitra tentang pengolahan hasil seba gai sumber a lternatif pendapatan dari usaha budidaya ternak babi, dan belum dilakukannya analisa usaha ternak babi sebagai indikator mengetahui keuntungan anggota petemak mitra

Profil usaha budidaya ternak babi yang dilakukan di kelompok tani Sehati saat ini diketahui memiliki jumlah 2-3 ekor per anggota kelompok, menggunakan bibit babi lokal sehingga mempengaruhi lama waktu pemeliharaan untuk mencapai bobot jual (12-15 bulan) serta diberikan pakan seadanya. Pada sisi yang lain, terba tasnya modal yang dimiliki anggota mitra telah disia sati dengan melakukan pembatasan jumlah temak babi yang dipelihara sehingga berdampak kepada tingkat keuntungan yang relatif kecil, sementara pinja man modal sulit diperoleh.

Pemasaran ternak babi di kelompok tani Sehati umumnya dilakukan secara terbatas di rumah, dan sebagian lainnya dijual di pasar lokal dengan tidak mengetahui secara pasti harga jual yang layak dan menguntungkan setelah dikurangi dengan biaya produksi selama masa pemeliharaan yang menyebabkan tingkat keuntungan yang minim serta penerapan teknologi penggemukan dan manfaatnya belum dilakukan. Dinyatakan demikian karena sesungguhnya melalui kegiatan penggemukan akan diperoleh manfaat, yakni mempersingkat waktu pemeliharaan, memudahkan keseragaman pemberian pakan dan minum, mempercepat peningkatan bobot badan, meminimalkan resiko penjualan yang tidak terjadwal, dan memudahkan di dalam pengawasan maupun perhitungan ekonomi usaha. Hal ini sesuai pemyataan Ilham (2002) dan Sihombing (2006) disita si Suranjaya, dkk (2017) bahwa usaha penggemukan ternak babi dengan jumlah kepemilikan yang terbatas merupakan ciri khas usaha peternakan rakyat, namun secara ekonomi kegiatan tersebut sesungguhnya akan memberikan keuntungan yang besar sehingga dapat dioptimalkan sebagai usaha penunjang ekonomi keluarga.

Berdasarkan permasalahan peternak tersebut, maka solusi yang ditawarkan untuk mengoptimalkan pemeliharaan ternak babi pada kelompok tani Sehati a dalah kerjasama penggemukan ternak babi dengan sistem kemitraan. Hal tersebut diimplementasikan 
melalui introduksi pengetahuan dan keterampilan penggemukan ternak babi, penyediaan input dan sarana produksi, perguliran ternak babi penggemukan kepada anggota lainnya, dan pendampingan terhadap aktivitas penggemukan maupun pemasaran ternak babi.

\section{BAHANDAN METODE}

Berdasarkan permasalahan mitra yang diidentifikasi maka solusi yang ditawarkan adalah:

1. Penyediaan bibit unggul (persila ngan Landrace dan Duroc) sebagai modal sa prodi untuk meningkatkan skala usaha penggemukan ternak babi (ternak babi yang disediakan sebanyak 10 ekor)

2. Introduksi sistim manajemen penggemukan temak babi.

Metode pendekatan untuk penyelesaiannya dengan menggunakan metode berikut:

\section{Penyuluhan}

Kegiatan ini dilakukan dengan memberikan materi penyuluhan tentang sistim kemitraan khusus temak babi, cara pemeliharaan ternak babi melalui sistem penggemukan, perkandangan, cara pemasaran temak babi, dan perhitungan ekonomis harga jual temak babi saat pemasaran. .

\section{Diskusi / Pelatihan}

Diskusi dilakukan dengan memberikan kesempatan pa da mitra baik padasaat penyuluhan maupun pada saat demplot, atau pendampingan peternak. Hal yang didiskusikan umumnya berkaitan dengan seluruh aspek penggemukan ternak babi melalui tanya jawab, pemberian contoh kasus, serta latihan penyelesaian contohkasus.

\section{Demonstrasi Plot / Praktik Lapang}

Kegiatan yang dilakukan adalah dengan memberikan demplot cara pemeliharaan ternak babi penggemukan seca ra la ngsung serta cara menyusun ransum temakbabi penggemukan dengan menggunakan bahan pakan lokal yang tersedia. Kegiatan ini dilakukan bersama-sama dengan mitra.

\section{HASIL DAN PEMBAHASAN}

Berdasarkan metode kegiatan maka, kegiatan pengabdian dilakukan dengan terlebih dahulu melakukan pendekatan dengan mitra guna mem persiapkan kandang penggemukan model in dividu. Kandang yang disedia kan berukuran 0,78 x 2,00 m dengan tinggi 1,20 m yang terbuat dari bahan besi beton. Selanjutnya dilakukan persiapan pakan yang berasal dari pabrik pakan milik Politekik Pertanian Negeri Kupang.

Kandang yang dibuat sebanyak 10 unit dan pada saat kandang telah disiapkan kemudian dilakukan pendekatan kepada mitra guna penyerahan anak babi bibit. Ternak babi unggul yang diberikan sesuai kesepakatan adalah babi hasil persilangan bangsa Landrace x Duroc. Ternak babi unggul diperoleh di Instalasi Pembibitan Ternak Babi milik Dinas
Peternakan Kota Kupang sebanyak 10 ekor dengan kriteria bobot badan terendah adalah $10 \mathrm{~kg}$.

Pelaksanaan selanjutnya adalah menga dakan diskusi dengan mitra untuk pelaksanaan penyuluhan dan demplot. Tim dan mitra kemudian memutuskan bahwa tempat pelaksanaan dilakukan di rumah ketua mitra, namun karena alasan angin kencang dan suhu yang dingin sehingga tempat pelaksanaan dipindahkan ke aula gereja.

Pada saat pelaksanaan kegiatan peserta yang hadir penyuluhan bukan hanya anggota mitra melainkan anggota masyarakat sekitar sehingga pengetahuan tentang manajemen pemeliharaan ternak yang diberikan dapat diketahui oleh semua masyarakat dengan baik. Hal ini menyebabkan peningkatan pengetahuan masyarakat dapat dicapai secara menyeluruh. Selain penyuluhan kegiatan dilanjutkan dengan demplot tentang penyusunan pakan ternak babi khususnya babi fase grower. Kegiatan penyuluhan dan demplot berlangsung dengan suasana kekeluargaan sehingga peserta merasa antusias untuk melakukan diskusi seputar massalah peternakan.

Mitra juga dilibatkan secara mandiri dalam pemeliharaan ternak babi introduksi sesuai dengan manajemen pemeliharaan ternak babi yang telah disuluhkan. Pemeliharaan ternak babi dila kukan selama \pm 5 bulan hingga pemasaran. Penggemukan yang dilakukan didahului dengan melakukan penimbangan bobot badan awal yang kemudian dilanjutkan penimbanganya setiap bulan. Hal ini dilakukan agar tim dan mitra mengertahui pertumbuhan ternak dengan baik. Data tentang pertumbuhan ternak ini akan dijadikan bahan evaluasi untuk pengadaan temak babi bibit dan manajemen pemberian pakan pada pemeliharaan periode berikutnya.

Masalah yang ditemukan dalam pelaksanaan pengabdian seperti terda pat babi yang terkena diare maka mitra berkomunikasi langsung dengan tim pengabdian dan bersama tim kemudian mengambil langkah pengobatan diare dengan menghubungi dokter hewan. Berdasarkan hasil pelaksanaan kegiatan pengabdian, maka terdapat beberapa perubahan yang terja di sebagai optimalisasi pemeliharaan ternak babi penggemukan sistim kemitraan yang disajikan pada Tabel1.

Tabel 1. Perubahan optimalisasi pemeliharaan ternak babi.

\begin{tabular}{|l|l|l|}
\hline \multirow{2}{*}{ Kegiatan } & \multicolumn{2}{|l|}{$\begin{array}{l}\text { Perubahan yang terjadi akibat } \\
\text { kegiatan pengabdian }\end{array}$} \\
\cline { 2 - 3 } & Sebelum & Sesudah \\
\hline Pengetahuan & Mitra tidak & Mitra telah \\
mitra tentang & mengetahui & mengetahui \\
manajemen & manajemen & dengan baik \\
pemeliharaan & pemeliharaan & mengenai \\
ternakbabi & ternak babi & ukuran \\
& dengan baik & kandang, \\
\hline
\end{tabular}




\begin{tabular}{|c|c|c|}
\hline & $\begin{array}{l}\text { yang ditandai } \\
\text { perkandangan, } \\
\text { pemberian } \\
\text { pakan, dan } \\
\text { pemilihan bibit } \\
\text { babi yang } \\
\text { dilakukan } \\
\text { seadanya }\end{array}$ & $\begin{array}{l}\text { pakan, dan cara } \\
\text { pemeliharaan } \\
\text { ternak babi } \\
\text { yangbaik. }\end{array}$ \\
\hline $\begin{array}{l}\text { Performans } \\
\text { pertumbuhan } \\
\text { ternak babi } \\
\text { (berda sarkan } \\
\text { pertambahan } \\
\text { bobot } \\
\text { badan/PBB)* }\end{array}$ & $\begin{array}{l}\text { PBB rendah } \\
\text { rata-rata } 0,18 \\
\text { kg/hari } \\
\text { (pemeliharaan } \\
\text { dengan pakan } \\
\text { seadanya) }\end{array}$ & $\begin{array}{l}\text { PBB meningkat } \\
\text { rata-rata } 0,36 \\
\mathrm{~kg} / \text { hari }\end{array}$ \\
\hline $\begin{array}{l}\text { Lama } \\
\text { pemeliharaan } \\
\text { mencapai } \\
\text { bobot jual ( } 60 \\
\mathrm{~kg} \text { ) }\end{array}$ & $\begin{array}{l}\text { Lama } \\
\text { pemeliharaan } \\
\text { berkisar } 12-15 \\
\text { bulan }\end{array}$ & $\begin{array}{l}\text { Lama } \\
\text { pemeliharaan } \\
\text { berkisar } \quad 6-7 \\
\text { bulan }\end{array}$ \\
\hline $\begin{array}{l}\text { Hubungan } \\
\text { sosial mitra }\end{array}$ & $\begin{array}{l}\text { Bekerja sendini } \\
\text { dirumah tangga } \\
\text { masing-masing }\end{array}$ & $\begin{array}{l}\text { Bekerjasama } \\
\text { menyelesaikan } \\
\text { semua } \\
\text { persoalan } \\
\text { peternakan } \\
\text { (pemeliharaan } \\
\text { awal hingga } \\
\text { pemasaran) }\end{array}$ \\
\hline
\end{tabular}

Keterangan ; *Berdasarkan 2 bulan pemeliharaan setelah sapih

Berdasarkan Tabel 1 diketahui bahwa terjadi optimalisasi pemeliharaan ternak babi. Hal ini terlihat dari manajemen pemeliharaan yang dilakukan yakni dengan adanya sistim mitra, maka terdapat pembagian tugas yang jelas antara mitra (jika berhalangan dikomunikasikan dengan anggota lainnya) dalam hal pemeliharaan ternak babi mulai dari pembersihan kandang dan ternak hingga pemberian makan dan minum yang dilakukan secara terkoord inir sehingga ternak babi yang dipelihara tidak terlantar atau kela paran. Kebiasaan ini juga menyebabkan hubungan sosial mitra dalam masyarakat menjadi lebih a krab serta berbagai diskusi guna mengatasi masalah ternak babi da pat dilakukan setiap saat.

Kemitraan dengan sistim penggemukan ini juga menyebabkan peningkatan performans pertumbuhan dan pemeliharaan ternak babi. Hal ini terlihat dari pertambahan bobot badan (PBB) ternak babi yang meningkat jika dibandingkan dengan pemeliharaan sebelumnya. Peningkatan PBB ini memberikan nilai positif terhadap lama pemeliharaan mencapai bobot jual ( $\pm 60 \mathrm{~kg}$ ) yang lebih singkat. Dinyatakan demkian karena dengan PBB $0,36 \mathrm{~kg} /$ hari dan dengan lama pemeliharaan 5 bulan (150 hari) maka bobot jual yang dica pai adalah $54 \mathrm{~kg}$ dan jika ditambah $\pm 10 \mathrm{~kg}$ (bobot awal pemeliharaan) maka dalam waktu 5 bulan tersebut sudah dicapaibobotjual $64 \mathrm{~kg}$. Jika dibandingkan PBB $0,18 \mathrm{~kg} /$ hari (pemeliharaan babi lokal atau babi persilangan yang dilakukan seadanya), maka untuk mencapai bobot jual $64 \mathrm{~kg}$ tersebut membutuhkan waktu 355,56 atau 356 hari ( 11,87 bulan a tau 12 bulan).

Pertambahan bobot badan ternak babi tersebut lebih rendah seperti rekomendasi NRC (1998) yakni pertambahan berat badan ternak babi dengan berat ba dan sekitar $10 \mathrm{~kg}$ sampai $60 \mathrm{~kg}$ berkisar 500 gr sampai 750 gr. Hal ini dika renakan bibit babi yang digunakan bukan merupakan babi a sli melainkan hasil persilangan Landrace X Duroc, temperatur lingkungan, dan cara pemeliharaan yang berbeda dengan daerah a sal temak babiunggul tersebut.

\section{KESIMPULAN}

Berdasarkan hasil kegiatan disimpulkan bahwa optimalisasi pemeliharaan ternak babi penggemukan dengan sistim kemitraan dapat meningkatkan pengetahuan dan ketrampilan mitra dan masyarakat, menghasilkan performans ternak babi dengan PBB 0,36 $\mathrm{kg} /$ hari den gan la ma pemeliharaan mencapai bobot jual $(60 \mathrm{~kg})$ selama 5 bulan, serta hubungan sosialmitra dan masyarakat yang lebih akrab. Disara nkan a gar sistim kemitraan ini dapat diadopsi oleh pemerintah setempat dan dilakukan pada peternak lainnya a gar ekonomi masyarakat semakin baik.

\section{UCAPAN TERIMA KASIH}

Terima kasih disampaikan kepada KEMENRISTEKDIKTI, kepala pusat P2M, dan pimpinan Politeknik Pertanian Negeri Kupang atas dana DIPA yang diberikan untuk memfasilitasi kegiatan pengabdian ini.

\section{DAFTAR PUSTAKA}

Johns C, Cargill C, Patrick I, Geong M, dan Johanis. 2010. Budidaya Ternak Babi Komersial oleh Peternak Kecil di NTT-Peluang untuk Integrasi Pasar yang Lebih Baik. Laporan Akhir ACIAR. Canberra (Australia): Australian Centre for International Agricultura1 Research.

NRC, 1998. Nutrient Requirements of Swine. 10th Resived Ed. The National Academies Press.

Pardosi, U. 2004. Pengaruh Perkawinan antara Tiga Bangsa Babi terhadap Prestasi Anak dari Lahir sampai Sapih di PT. Mabarindo Sumbul Multifarm. Tesis. Fakultas Peternakan. Universitas Diponegoro. Semarang.

Soewandi, B. D. P dan C. Talib. 2015. Pengembangan Ternak Babi Lokal di Indonesia. WARTAZOA, vol. 25, no 1. hh. 39-46.

Suranjaya, I. G, M. Dewantari, I. K. W. Pa rimartha, dan I. W. Sukanata, 2017. Profile Usaha Petemakan Babi Skala Kecil di Desa Puhu Kecamatan Payangan Kabupaten Gianyar. Majalah Ilmiah Peternakan. vol.20, no. 2. hh. 79-83.

Sution, 2010. Beternak Babi. Balai Pengkajian Teknologi Pertanian. Kalimantan Barat. 